in which channels were quickly cut was "very much shattered by close jointing". It is no doubt a little remarkable that, supposing these trench valleys to be, geologically speaking, rather ancient, their sides are not more furrowed; but water-worn valleys in the Bunter pebble-beds, the Neocomian Sands, and the Chalk downs of Southern England often have their sides unfurrowed, and cliffs of limestone, on a comparatively small scale in England and on a gigantic one in the Alps, are frequently smooth for considerable distances, showing that atmospheric denudation has about kept pace with that from streamlets. The same sometimes holds good with sandstone and granite.

Finally, they forget that the invasion of the larger part of England by great ice-sheets is just as much an hypothesis as that of submergence, and cannot be regarded as an axiom until the difficulties to which I have repeatedly referred have been fairly met (instead of being ignored) and removed. I may add that I cannot accept as moraines (with which I ought to be familiar) several of those to which some geologists give that name. But my pamphlet will fulfil its purpose if it leads to a more careful study of the whole question, instead of such reasoning as this: "Here is a peculiar valley: how can we associate it with terrestrial ice-sheets?" To me the safer method seems this : "Here are certain physical facts: what inference do they suggest?" I do my best to keep "my mind from being set awhirl" when it arrives at a conclusion which is contrary either to a popular opinion or to what I was taught in my younger days.

T. G. Bonner.

\title{
A METHOD OF HARDENING FRIABLE FOSSIL WOOD FOR
} SECTION-CUTTING.

SIr, - While collecting from the Lower Gault in the neighbourhood of Farnham, Surrey, I often found fragments of what was evidently driftwood lying amongst the shells. It was extremely friable; in fact, when dry, it was, as a rule, impossible to touch it or even blow upon it without causing it to fall away in powder; and to obtain a section from such material seemed well-nigh impossible.

When treated in the usual way with silica solution the wood did not appear to be permeated, but merely to be-in the mechanic's term - 'case-hardened,' that is, to have formed on the surface a very thin crust of hardened substance, rendering the specimen useless for section-cutting.

It occurred to me, however, that a better result might be obtained by forcing the silica solution into the wood, on the same principle as that by which railway-sleepers are impregnated with creosote under pressure. An ordinary model steam-engine boiler was, accordingly, adapted for the purpose. First the filling hole was enlarged enough to admit a piece of the wood, and a certain fitting, stocked by all model makers, added. This consists of an ordinary bicycle tyre valve threaded on the outside to screw into the boiler. This attached, sufficient silica solution (undiluted) was poured in to cover the wood, the filler-cap screwed on, and the boiler pumped up with an ordinary cjcle-pump. The pressure was raised to $30 \mathrm{lb}$. per square inch, 
and the whole left for five days, except that it was occasionally pumped up to maintain the pressure, which dropped rather rapidly; in fact, on several occasions, namely at night, there can have been no pressure at all for some hours, as it was always necessary to have recourse to the bicycle pump in the morning. On being taken out after five days, the wood was found to be much harder, or rather, it was tough-I could make no impression on the wood by scratching with my finger-nail, but it had a hard leathery feeling when scratched. It was now allowed to dry by simple exposure to the air in my workshop, and in six days more appeared to be dry.

I should add that before hardening it as above described $I$ had managed to cut one end of the wood flat, across the grain. The wood being dry, I now attempted to polish it by simple rubbing against a soft cloth, and obtained a fair polish, but, not having the necessary apparatus or skill to cut a section, I gave the specimen to the British Museum of Natural History, where it now is. Hoping that this description may be of use to others.

The Chine, Wrecclesham, Farnham.

Christian Tinne. January 6, 1916.

\section{WILLIAM SMITH'S MAPS.}

SIR,-I am preparing a monograph on Smith's maps, etc., for the Yorkshire Geological Society, and am anxious to see a "Reduction of Smith's large Geological Map of England and Wales intended as an elementary map for those commencing the study of Geology, 1819", referred to in Phillips's Memoirs of Smith.

I find that Smith's large maps of 1815 often bear a signature and a number, such as "No. 66" or "a 33 ". If any readers of the Geological Magazine possess copies of this large map, perhaps they would kindly inform me what number the map bears. It occurs under the "Section of Strata", which appears on the map to the east of the Humber estuary.

The Museums, HulL.

T. SHEPPARD. January $25,1916$.

OBITUARY.

\section{HERMANN GRAF ZU SOLMS-LAUBACH,}

Sc.D., For. M.Roy. Soc., For. M.Linn. Soc., For.M. Geol. Soc.

BORN DECEMBER 23, 1842.

DIED NOVEMBER 24, 1915.

Count Solms-Ladbach was well known amongst men of science as a most distinguished botanist. His death was communicated to this country by Professor A. G. Nathorst, the Swedish Palæontologist of Stockholm.

Count Solms was born in 1842, and was in his 73rd year. He devoted his life wholly to science. He was Professor of Botany at Göttingen and afterwards at Strasburg, from which he retired a few years since. 